\title{
1. A brief history
}

The history of the EEC has been told many times. The early years of the European Coal and Steel Community (ECSC) have also received some attention in the literature. The origins of the Euratom are perhaps less well known. ${ }^{1}$ This chapter briefly explores the Euratom's origins and its evolution during its founding period. Why did it come into being? In what political and economic context was it shaped? What expectations did the founding Member States have of the new organisation?

The chapter also explores what could be described as the Euratom's 'formative years'. Why did Euratom lose its momentum as the main instrument in the European integration process? Why was the EEC regarded as such a success, while the Euratom was regarded as a failure? Why has the Euratom survived?

These issues are of relevance because they give us a wider understanding of the Euratom in the EU today. This chapter merely addresses the most significant staging posts, in order to set the scene for the subsequent chapters.

\subsection{THE BIRTH OF EURATOM}

In the post-war period, it was recognised early on that international cooperation would be a necessity for making scientific advances, for economic prosperity and to foster peace. The nuclear industry was, however, still in its infancy. In 1946, a UN Atomic Energy Commission was convened. The United States, which had the most developed nuclear energy programme at that time, was leading the efforts to create an international framework.

Following the US President Eisenhower's famous 'Atoms for Peace' speech to the UN General Assembly in 1953, ${ }^{2}$ the United States started

1 But see Peter Weilemann, Die Anfänge der Europäischen Atomgemeinschaft: zur Gründungsgeschichte von EURATOM 1955-1957 (Baden-Baden: Nomos Verlagsgesellschaft, 1983).

2 Speech by Dwight D. Eisenhower, President of the United States of America, to the 470th Plenary Meeting of the United Nations General Assembly, 
to liberalise its nuclear legislation and conclude international agreements. Two international scientific conferences on the Peaceful Uses of Atomic Energy, held in Geneva in 1955 and 1958, were also of importance. They underlined that nuclear energy would soon be economically competitive. In 1957, the International Atomic Energy Agency (IAEA) was established.

There was an enormous demand for energy in post-war Europe. This demand, coupled with the need to integrate Europe after the war, explains why in 1951 the governments of Germany, Belgium, France, Italy, Luxembourg and the Netherlands established the ECSC. ${ }^{3}$ A few years later, the six Member States took a further step towards integration with the creation of a European Defence Community. The project was shelved after the French assembly rejected it, and that failure led to a temporary halt in the European integration process. However, integration would soon regain its momentum.

In 1953, the Organization for European Economic Co-operation (OEEC) (now the Organisation for Economic Co-operation and Development (OECD)) published a memorandum on Europe's energy future, ${ }^{4}$ which stressed that the rising energy costs could have an adverse effect on economic development. It became increasingly clear that indigenous energy production (coal in particular) could not meet the rising demand. In 1955, Louis Armand (later the Euratom's first president) ${ }^{5}$ prepared a report for the OEEC, which not only underlined the energy need, but also the enormous potential of nuclear energy. He pointed out that nuclear energy required international cooperation to a much higher degree than any other energy form, especially with regard to information exchange and the joint financing of nuclear power plants.

In 1955, the Benelux countries issued a Joint Memorandum on the initiative of Paul H. Spaak, Belgium's Minister for Foreign Affairs. They proposed widening the competences of the ECSC; harmonisation of social issues; the establishment of a general common market; and

8 December 1953, available at the IAEA's website: https://www.iaea.org/about/ history/atoms-for-peace-speech, accessed 1 October 2017.

3 Treaty establishing the European Coal and Steel Community (ECSC Treaty), Paris, 18 April 1951, entered into force 24 July 1952, 261 UNTS 141, No 3729.

4 The OEEC was established in 1948 to manage the economic aid provided under the Marshall Plan.

5 See Louis Armand, 'Some Aspects of the European Energy Problem: Suggestions for Collective Action', Report prepared for the OEEC, June 1955. 
cooperation in transport and energy, in particular nuclear energy. ${ }^{6}$ At the Messina Conference the same year, the six ECSC Member States adopted a resolution based on this memorandum, stressing that ' $[\mathrm{t}] \mathrm{he}$ development of atomic energy for peaceful purposes will very soon open up the prospect of a new industrial revolution beyond comparison with that of the last hundred years'. The Messina Resolution recommended the study of the creation of a 'joint organization'. ${ }^{7}$

An intergovernmental committee was subsequently set up and tasked with examining the possibilities for the 'revival of Europe' and applying the Messina Resolution. It submitted a detailed report, commonly known as the Spaak Report, on the establishment of a European Atomic Energy Community. ${ }^{8}$ The Ministers of the six countries decided that the Spaak Report would be the basis for drafting a Treaty on the Common Market and on the Euratom. At the Intergovernmental Conference in July 1956, two expert working groups were formed, one for the Euratom and one for the general Common Market. Their tasks were to prepare drafts for the new treaties.

The Spaak Report was largely based on a French proposal, ${ }^{9}$ which included a common supply agency that would have common ownership of all fissionable materials in the Member States; the construction of a reprocessing plant for the European nuclear industry; the coordination and financing of national and community research; the exchange of patents; and the creation of a nuclear common market. Some of the French ideas were met with reluctance, in particular the proposal for a joint European enrichment plant and a supply agency. These ideas were part of the French strategy to break the American monopoly of enriched uranium. ${ }^{10}$ The supply agency would buy French natural uranium, which

6 Memorandum from the Benelux countries to the six Member States of the ECSC, 18 May 1955.

7 Resolution adopted by the Foreign Ministers of the ECSC Member States, Messina, 1-3 June 1955.

8 Rapport de la commission de l'énergie nucléaire, Bruxelles, 5 novembre 1955.

9 See Christian Deubner, 'The Expansion of West German Capital and the Founding of Euratom' (1979) 33 International Organization 203, 215; and Memorandum Note de la délégation française, Bruxelles, le 18 juillet 1955.

10 Natural uranium consists of two isotopes, U-235 and U-238. Only the $\mathrm{U}-235$ isotope is fissionable. Natural uranium contains $0.7 \%$ of the U-235 isotope (and $99.3 \%$ of the U-238 isotope), but this concentration is not sufficient for using it as a fuel in the most common types of reactors. The concentration of U-235 has to increase. This is done through a process of isotope separation: natural uranium is 'enriched' until the concentration of U-235 reaches 3-5\%. 
would be processed in a joint European enrichment plant. There would be no need to buy American enriched uranium. ${ }^{11}$ But the West German industrialists feared that French uranium prices would be too high and that they would be better off concluding bilateral agreements with the United States. ${ }^{12}$ Eventually, the French idea of a European enrichment plant was shelved. The West German government declared itself willing to support the Euratom project, despite the industrialists' strong resistance. ${ }^{13}$ But it was suggested early on that it was a mistake not to take these objections into account. ${ }^{14}$

Another important issue was whether to include a prohibition on the development of nuclear weapons. France strongly opposed this proposal. ${ }^{15}$ There were also concerns that a prohibition could threaten the endeavour to form a bloc independent from the United States and the Soviet Union. ${ }^{16}$ A prohibition was never introduced in the Treaty.

The discussions also revolved around which form of cooperation would be the most suitable for nuclear energy. One faction wanted a conventional, intergovernmental European cooperation. The OEEC was suggested as a suitable framework. Another faction wanted a supranational organisation, intended to lead to integration among its Member States. This was finally chosen as the most suitable institutional solution.

The Action Committee for a United States of Europe, ${ }^{17}$ formed by Jean Monnet, recommended that the six foreign ministers appoint 'Three Wise Men' to present a report on Europe's energy needs and review the possibilities of drawing up a programme for nuclear power. The report, 'A Target for Euratom', published in May 1957,18 warned that economic

Some reactors require an even higher concentration. To produce nuclear weapons, the concentration has to be around $90 \%$.

11 Deubner, 'The Expansion of West German Capital and the Founding of Euratom' (n 9) 216.

12 Jonathan E. Helmreich, 'The United States and the Formation of EURATOM' (1991) 15 Diplomatic History 387, 394.

13 Deubner, 'The Expansion of West German Capital and the Founding of Euratom' (n 9) 207.

14 Allan Nanes, ‘The Evolution of Euratom' (1957/58) 13(1) International Journal 12, 17.

15 Helmreich, 'The United States and the Formation of EURATOM' (n 12) 400-401.

16 Nanes, 'The Evolution of Euratom' (n 13) 18.

17 See Résolution du Comité d'action pour les Étas-Unis d'Europe exposant les motifs de la déclaration commune du 18 janvier 1956.

18 Louis Armand, Franz Etzel and Francesco Giordani, 'A Target for Euratom', Report submitted at the request of the governments of Belgium, France, 
growth was in danger; Europe was too dependent on uncertain imports of coal and oil, especially from the volatile Middle East. The advent of nuclear power was a solution to this problem. The establishment of the Euratom would offer the means to achieve their envisaged target - 'the construction of 15 million $\mathrm{kW}$ of nuclear plant by the end of 1967'. In drawing up the report they consulted closely with the United States, which supported the plan. It was a timely report, published just months after the Suez Crisis, which had underlined the importance of a secure energy supply.

In 1957, the Member States subsequently signed the two Rome Treaties. In 1958, the Euratom Treaty and the EEC Treaty came into force after all six Member States had ratified them. ${ }^{19}$

\subsection{EXPLAINING THE CREATION OF EURATOM}

As outlined, in the 1950 s, nuclear energy was seen as a very promising source of energy. The original Member States believed that the development of nuclear energy would pave the way for economic prosperity in Europe, and even open up a new industrial revolution. ${ }^{20}$ The development of new technologies was seen as the only solution for a situation with scarce supply that threatened to become an obstacle to economic growth. ${ }^{21}$ But the cost of conducting research and constructing reactors was too high for individual Member States to bear separately. It was realised that the cost had to be shared and the duplication of efforts avoided. $^{22}$ The Member States also believed that the Euratom was

German Federal Republic, Italy, Luxembourg and the Netherlands, 4 May 1957, available at www.ena.lu/report_wise_men_euratom_1957-2-1281 (hereinafter 'The Three Wise Men Report').

19 Treaty establishing the European Economic Community ('EEC Treaty'), Rome, 25 March 1957, in force 1 January 1958, 294 UNTS 3, No 4300; and Treaty establishing the European Atomic Energy Community ('Euratom Treaty'), Rome, 25 March 1957, in force 1 January 1958, 294 UNTS 259, No 4301.

20 See Resolution adopted by the Foreign Ministers of the ECSC Member States, Messina, 1-3 June 1955.

21 The Three Wise Men Report, 2.

22 Nanes, 'The Evolution of Euratom' (n 14) 13; Helmreich, 'The United States and the Formation of EURATOM' (n 12) 393. 
necessary for the general common market to succeed; a successful Common Market would lead to an expansion of production. ${ }^{23}$

While the economic rationale behind the creation of the Euratom seems to have been fundamental, the political rationale was also of major importance. Europe was short of domestic energy supplies, which made it dependent on foreign sources. ${ }^{24}$ The availability of imported energy was uncertain, and this threatened not only Europe's economic growth, but also its political security. As Jean Monnet remarked, the political situation following the Suez Crisis in 1956 'made all of Europe more power conscious and more receptive to the joint development of atomic energy'. ${ }^{25}$ Further, technology was equated with power, ${ }^{26}$ and Euratom would make Europe into a third power that would be economically and militarily independent of the United States. ${ }^{27}$

The aim of European integration was central in the creation of both Communities. ${ }^{28}$ But it was the Euratom - and not the EEC - that was seen as the main instrument for integration. ${ }^{29}$ The nuclear field was considered as being a particularly promising area because (as it was then believed) the vested interests were few. The EEC project was more uncertain. ${ }^{30}$ France did not want the Common Market, but had proposed a sectoral cooperation on nuclear development. ${ }^{31}$ As Deubner explains: ${ }^{32}$

23 Reuben Efron and Allan Nanes, 'The Common Market and Euratom Treaties: Supranationality and the Integration of Europe' (1957) 6 International \& Comparative Law Quarterly 670.

24 The Three Wise Men Report, 14.

25 See Helmreich, 'The United States and the Formation of EURATOM' (n 12) 404.

26 Nanes, 'The Evolution of Euratom' (n 14) 20.

27 Jaroslav G. Polach, EURATOM: Its Background, Issues and Economic Implications (New York: Dobbs Ferry, 1964) 61.

28 Andrew Moravcsik, The Choice for Europe: Social Purpose and State Power from Messina to Maastricht (Ithaca, NY: Cornell University Press, 1998) 87.

29 This was the view of Jean Monnet: see Moravcsik, ibid 91, 145; Helmreich, 'The United States and the Formation of EURATOM' (n 11) 393 (further explaining that this was also the view of Dulles, the US Secretary of State, at 400); and Lawrence Scheinman, 'Euratom: Nuclear Integration in Europe' (1967) 36(563) International Conciliation 8. See also Deubner, 'The Expansion of West German Capital and the Founding of Euratom' (n 9) 225.

30 Deubner, 'The Expansion of West German Capital and the Founding of Euratom' (n 9) 207.

31 Ibid.

32 Ibid, 206. 
The negotiations on Euratom were important in two ways: first, they provided an apparently realistic short-to-medium-range objective for European integration when prospects for a general common market seemed dim; second, they kept the French in the integration talks and thereby facilitated eventual agreement by the French to a common market.

Thus, the Euratom 'was neither an irrelevant peripheral affair in the shadow of the Common Market negotiations nor was it merely a vehicle for the realisation of the EEC'. ${ }^{33}$ The Euratom was a necessary instrument to avoid losing momentum in the integration process.

The United States, which dominated the nuclear field at the beginning of the 1950s, played an important role in the creation of the Euratom. ${ }^{34}$ The United States not only had the most advanced technology, but, together with the United Kingdom, it was also controlling the world supply of uranium. ${ }^{35}$ In 1944, the United States had entered an agreement with Belgium, which gave it access to uranium in the Belgium Congo, the major supplier of ores at that time. In exchange, Belgium received information on nuclear energy technology, as well as enriched uranium for nuclear reactors. For France, it was crucial that the privileges under the bilateral agreement between the United States and Belgium could be transferred to the Euratom framework. ${ }^{36}$ France wanted access to the United States' technological information and nuclear materials. ${ }^{37}$

The United States supported the Euratom project, ${ }^{38}$ and declared itself willing to 'arrange for the integrated group to assume the rights and

33 Ibid.

34 For a discussion of the role of the United States in the creation of the Euratom, see Helmreich, 'The United States and the Formation of EURATOM' (n 12) 387-410.

35 The United States had very strict legislation (the US Atomic Energy Act of 1946). There were, e.g., limitations on exchange of technical information on nuclear energy between the United States and other countries. The legislation was eased by the US-Euratom Cooperation Act of 1958. Deubner, 'The Expansion of West German Capital and the Founding of Euratom' (n 9) 208.

36 Helmreich, 'The United States and the Formation of EURATOM' (n 12) 392.

37 In the 1950s, France was the only Member State that had started to apply nuclear power on an industrial scale. The other Member States were engaged in reactor development projects, but nuclear power was still at an experimental stage. The Three Wise Men Report, 7.

38 Helmreich, 'The United States and the Formation of EURATOM' (n 12) 387-410. The Three Wise Men Report also emphasised the important role of the United States in the formation of Euratom (at 7). 
obligations of the Government of Belgium under this Agreement'. ${ }^{39}$ The uranium would be available to the Euratom Member States and they would also get access to technological information from the United States. ${ }^{40}$ Shortly after the Euratom Treaty had come into force, the Euratom concluded an agreement with the United States giving American firms access to the Euratom market and to the Euratom's technological information.

The United States' support also had some cold war considerations. ${ }^{41}$ The Euratom would help to resist the Soviet Union's expansionist ambitions by providing technological and economic competition. The support was also a way to advance the image of the United States as primarily interested in developing nuclear energy for peaceful purposes. Moreover, it would strengthen the ties between the United States and Europe and it would reduce Europe's dependence on oil from the Middle East. Last, but not least, it was seen as a way to deal with West Germany and to further European integration after the failure to set up the European Defence Community. ${ }^{42}$

\subsection{INTERNATIONAL ORGANISATIONS IN THE NUCLEAR FIELD}

Two organisations were established in the same year as the Euratom: the International Atomic Energy Agency (IAEA) and the Nuclear Energy Agency (NEA, previously the European Nuclear Energy Agency (ENEA)). Their objectives and methods overlapped. ${ }^{43}$

The IAEA, which has 162 members, ${ }^{44}$ is the most important international organisation for cooperation in the nuclear field. Although it is an independent organisation, it has a close relationship with the UN, which is regulated by a special agreement. ${ }^{45}$ The IAEA also has a strong association with the Euratom. In 1976, a cooperation agreement was

\footnotetext{
39 Helmreich, 'The United States and the Formation of EURATOM' (n 12) 403.

40 Ibid.

41 Allan S. Nanes and Reuben Efron, 'The European Community and the United States: Evolving Relations' (1960) 22 The Review of Politics 175, 182.

42 Helmreich, 'The United States and the Formation of EURATOM' (n 11) $387,409$.

43 Michel Gaudet, EURATOM (London: Pergamon Press, 1959) 174-5.

44 See the IAEA's website: www.iaea.org/About/Policy/MemberStates/, accessed 19 September 2017.

45 International Atomic Energy Agency, The Texts of the Agency's Agreements with the United Nations, 30 October 1959, INFCIRC/11.
} 
concluded between the IAEA and the Euratom. ${ }^{46}$ According to this agreement, '[t]he Contracting Parties shall consult each other regularly on matters of mutual interest with a view to harmonizing their efforts, as far as possible, having due regard to their respective characters and objectives'. The agreement also allows the Euratom to participate in the IAEA's annual sessions, but it has no right to vote. In 2007, the IAEA and the Euratom reaffirmed their cooperation in a Joint Statement, in which the organisations emphasised 'their mutual determination to significantly reinforce the quality and intensity of their cooperation' ${ }^{47}$

The NEA was established under the OEEC (now the OECD). Its original aim and tasks were similar to those of the Euratom: it was dedicated to the promotion of the nuclear industry. Among its tasks, the NEA coordinates nuclear research and training. ${ }^{48}$

The Euratom was different from the IAEA and the NEA in the sense that it was a much closer cooperation between the Member States than in any of the other organisations. ${ }^{49}$ Only a supranational organisation would achieve the Member States' purposes in the field. Gaudet explains:

The member states of Euratom bind themselves by rules and put themselves in the hands of joint institutions in order to reach their objectives. The very broadness and urgency of the task before them has made them decide to pool their efforts, and they have agreed to provide the unity of decision which is a fundamental condition to such a pooling. Thus they have applied to a civilian international effort a classic principle of military alliances, that of a unified command.

\subsection{THE STILLBORN COMMUNITY?}

Not long after the entry into force of the Euratom Treaty, the original enthusiasm seemed to have disappeared. ${ }^{50}$ It became increasingly clear

46 Cooperation Agreement between the European Atomic Energy Community and the International Atomic Energy Agency [1975] OJ L329/28, 23 December 1975.

47 'Reinforcing Cooperation on Nuclear Energy for Peace and Development', A Joint Statement of the International Atomic Energy Agency and the European Commission, 7 May 2008.

48 The NEA aims at fostering the development of the production and uses of nuclear energy for peaceful purposes. See the Statute of the OECD Nuclear Energy Agency, as amended on 13 July 1995.

49 Gaudet, EURATOM (n 43) 174-5.

50 Christopher Layton, European Advanced Technology: A Programme for Integration (London: Allen and Unwin, 1969) 107. 
that the Euratom was a failure. Many of the Treaty provisions came to have little or no practical relevance, including what in the negotiations had been considered the most central ones. This was especially true for some of the more 'supranational' provisions (for example, as shall be explained, the provisions on the Supply Agency), which never came to function in the way they were intended. Some commentators argue that, in practice, the Euratom seemed to work more as an intergovernmental organisation than a supranational organisation; it was 'supplemental rather than exclusive'. ${ }^{51}$ Some commentators explain that the Euratom came only to play a minimal role as an instrument for European integration. ${ }^{52}$

How can this 'failure' be explained? Why did the EEC succeed but not the Euratom? There is a vast literature on what factors lead to political and economic integration, but less is written on when it does not work. Scheinman argues that a multitude of factors explain why the Euratom experience differed from the EEC. One factor was the absence of bargaining possibilities. The scope of different activities in the EEC facilitated bargaining; policy decisions were often developed in package deals covering more than one sector. This was not possible under the Euratom framework. ${ }^{53}$ The merger of the institutions in 1967 did not seem to have opened up for intra-Treaty bargaining.

But perhaps the most obvious explanation is that the economic realities had changed. ${ }^{54}$ Due to new discoveries of coal reserves, there was now a coal surplus in Western Europe. ${ }^{55}$ Further, the oil price had fallen due to the stabilised situation in the Middle East. As the price for conventional energy went down, nuclear power became less attractive. Furthermore, the overall energy demand was not as high as expected; 'Europe's energy problem', as outlined in 'A Target for Euratom', had clearly been overestimated. Scheinman writes that 'one of the principal ingredients that had nourished the relatively easy ratification of the Treaty had been withdrawn at alarming speed'. ${ }^{56}$

51 Scheinman, 'Euratom: Nuclear Integration in Europe' (n 29) 11.

52 Deubner, 'The Expansion of West German Capital and the Founding of Euratom' (n 9) 223; Polach, EURATOM: Its Background, Issues and Economic Implications (n 27) 128.

53 Scheinman, 'Euratom: Nuclear Integration in Europe' (n 29) 56-7.

54 Ibid, 27.

55 Alwyn V. Freeman, 'The Development of International Co-operation in the Peaceful Use of Atomic Energy' (1960) 54(2) The American Journal of International Law 383, 385.

56 Scheinman, 'Euratom: Nuclear Integration in Europe' (n 29) 27. 
However, if Euratom's failure could be explained only in terms of changes in demand and supply, the development of nuclear energy would also have lost its momentum on a national level. But this was never the case: the Member States continued to develop their national nuclear industries. The explanation lies somewhere else.

Scheinman argues that the failure can rather be explained by 'nuclear nationalism', ${ }^{57}$ which was particularly evident in the field of research; all the Member States viewed the Euratom as a competitor for nuclear scientists, technicians and money. As Scheinman explains, when the Euratom was about to assume its responsibilities in 1960, the national interests were already 'firmly entrenched'. ${ }^{58}$ The initial assumption that there were few vested interests in the nuclear field was clearly wrong. As one commentator had already argued at the end of the 1950s, 'there may yet be regrets for the ease with which Euratom was ratified'. ${ }^{59}$

France, which was the Community's most important nuclear power, ${ }^{60}$ had been Euratom's most enthusiastic supporter during the negotiations. But France had quickly become hostile to the project. Charles de Gaulle, who had come into power, was a strong opponent. The overriding goal for France had been European nuclear independence, but the price of a supranational system had become too high. France decided it would only participate in the Euratom's research activities on a very limited basis, ${ }^{61}$ and it prioritised its own national nuclear programme. France was also hostile to other activity areas. There was a general mistrust of activities that would set up limits to national sovereignty. Scheinman explains that France came to undermine Euratom by 'preventing [it] from serving its constituents effectively and in negating the scope and authority' ${ }^{62}$

France was not the only problem. In France, the nuclear industry was state-owned. In West Germany, private actors dominated the industry. The

57 Ibid, 35-51.

58 Ibid, 36.

59 Nanes, 'The Evolution of Euratom' (n 14) 16.

60 France invested considerably more in nuclear development than the other Member States. See Scheinman, 'Euratom: Nuclear Integration in Europe' (n 29) 31.

61 Ibid, 37.

62 Ibid, 35. France refused access to Euratom inspectors to the French plutonium facilities at Marcoule, arguing that this was a military installation, and therefore exempted from the Euratom safeguards provisions. On this episode, see Darryl A. Howlett, EURATOM and Nuclear Safeguards (Basingstoke: Macmillan and Centre for International Policy Studies, University of Southampton, 1990) 107-109; and Scheinman, 'Euratom: Nuclear Integration in Europe' (n 29) 37. 
German industrialists were very suspicious of the Euratom's supranational industrial dirigisme. ${ }^{63}$ Further, the Member States had divergent interests and priorities. The Netherlands and Belgium had limited capabilities to develop their own national nuclear programmes. They were the most enthusiastic of the original Six as they had much to gain from Euratom membership. ${ }^{64}$ Italy also had much to gain, but its goals were short term; Italy was mainly interested in securing cheap energy for its growing industry. By contrast, West Germany had long-term goals: it emphasised activity areas such as basic research, health protection and radioactive waste disposal. These disparities made it difficult to agree on a common agenda.

Further, all Member States saw the Euratom as a competitor. There was a rivalry between national programmes and the Euratom research programme; and in the Euratom's first decade it went through a serious crisis, which almost led to a complete meltdown.

\subsection{THE EURATOM CRISIS}

At the same time as the EEC went through the 'Empty Chair Crisis', 65 which was linked to agricultural policy, the Euratom had its own crisis linked to nuclear research. Just like the Empty Chair Crisis, the Euratom Crisis was partly caused by the advancement of political forces that wished to take a step back from European supranationalism. But the Euratom Crisis also had specific roots, and specific solutions. The crisis was grounded in deep political divisions over security of supply, dependency on foreign technology and the balance of power between the Member States. The core of the problem was the priorities set in the Euratom's research programmes and the Member States' different views on what Euratom research should look like. It should be noted that the

63 Deubner, 'The Expansion of West German Capital and the Founding of Euratom' (n 9).

64 Scheinman, 'Euratom: Nuclear Integration in Europe' (n 29) 32.

65 For an analysis, see, e.g., Jean-Marie Palayret, Helen S. Wallace and Pascaline Winand (eds), Visions, Votes, and Vetoes: the Empty Chair Crisis and the Luxembourg Compromise Forty Years On (Brussels: Peter Lang, 2006). See also the important works of Andrew Moravcsik, 'De Gaulle and European Integration: Historical Revision and Social Science Theory', Center for European Studies Working Paper Series Program for the Study of Germany and Europe Working Paper Series 8, 5 May 1998. 
crisis was limited to the Euratom; there was no crisis in other international organisations that dealt with nuclear research. In fact, nuclear cooperation in Europe blossomed outside the Euratom. ${ }^{66}$

The crisis started as a dispute over the choice of reactor technology, which the literature would refer to as the 'reactor war'. At the end of the 1950s, there were three main types of power reactors for commercial use: the gas/graphite reactors, the pressurised water reactors, and the boilingwater reactors. The first type (the gas/graphite reactor) used natural uranium as fuel, and the other two used enriched uranium. While natural uranium was relatively cheap and easily obtainable, enriched uranium was more expensive, and had to be imported; the Member States had no domestic source of enriched uranium. France used the first type (the natural uranium gas/graphite reactors) and wanted the Euratom to draw on this (French) technology instead on relying on foreign (American) technology. France argued that the Member States could secure its energy supply by using natural uranium gas/graphite reactors, as there would then be no need to import fuel. But some Member States were concerned about the French dominance in the nuclear technology field, and preferred to use American technology to close the gap between them and France. ${ }^{67}$

The Euratom Commission's first President, Louis Armand, was of the view that external technology would give the Euratom a flying start. ${ }^{68}$ As mentioned, in 1958, the Euratom entered a nuclear research and cooperation agreement with the United States. ${ }^{69}$ The agreement provided for a joint five-year research programme (which fell outside the Euratom's initial research programme) as well as a large-scale programme for the construction of American patent reactors. Eight enriched uranium reactors were to be supplied by American manufacturers. Under this agreement, the United States not only guaranteed the enriched uranium supply, but also provided a loan to the Euratom to facilitate the financing of the reactors.

66 Lawrence Julian Droutman, Nuclear Integration: The Failure of Euratom (Ann Arbor: UMI, 1982) 181.

67 Henry R. Nau, National Politics and International Technology: Nuclear Reactor Development in Western Europe (Baltimore: Johns Hopkins University Press, 1974) 108.

68 Ibid, 106.

69 Agreement for cooperation between the Government of the United States of America and the European Atomic Energy Community (Euratom) concerning peaceful uses of atomic energy (Unofficial translation), OJ 1959 No 17, 19 March 1959, p 312. 
To encourage participation in that reactor programme, the Euratom Commission recommended financial grants to participating projects. In exchange, the technical knowledge would belong to the Community. As there were no funds available in the Euratom budget for such financial grants, the Euratom Commission's second President, Etienne Hirsch (also French), proposed a transfer from unused funds of Euratom's own research programme. France opposed this and criticised the Commission for trying to subsidise foreign (American) technology. In the view of France, the transfer amounted to a change in the research programme, which required unanimous approval in the Council (Article 7 Euratom). But the Commission presented the transfer as a budgetary question, which only required a qualified majority. France was overruled in the Euratom Council. ${ }^{70}$

As a response to this episode, France refused to re-nominate Hirsch as the new President of the Euratom Commission. France appointed instead the Gaullist Pierre Chatenet and under his leadership, as Scheinman puts it, the Euratom 'evolved into a sterile body' ${ }^{71}$ France also made it clear that it would only approve the Euratom's new multiannual research programme under one condition: future budgetary transfers to the joint reactor programme would be considered as a change of the research programme, which, consequently, would require unanimous approval in the Council. This was the end of the joint financing of American projects.

The crisis also manifested itself in a difficulty to agree on the content of Euratom's multiannual research programmes. ${ }^{72}$ The second research programme (adopted for the years 1963-67) had to be revised due to increased costs, but only a very modest increase in the budget could be achieved. Guzzetti explains that this "made it plain that any "community spirit" had vanished from EURATOM'. ${ }^{73}$ In 1967, the Council discussions on adopting a third multiannual research programme failed. ${ }^{74} \mathrm{~A}$ new multiannual programme was not adopted until 1973. For many

70 See Scheinman, 'Euratom: Nuclear Integration in Europe' (n 29) 41-2; and Droutman, Nuclear Integration: The Failure of Euratom (n 66) 89-93.

71 Scheinman, 'Euratom: Nuclear Integration in Europe' (n 29) 51-3.

72 The first multiannual research programme was launched in 1959. Its details were provided for directly in the Treaty ('provisions relating to the initial period'). The successive programmes were adopted in accordance with the procedure in Article 7 Euratom.

73 Luca Guzzetti, A Brief History of European Union Research Policy (Luxembourg: OOPEC, 1995) 29.

74 See ibid, 29. See also 'Euratom's Future Activities', COM (1969) 350 final, 30 April 1969, Bulletin of the European Communities, Supplement No 6 1969. 
years, Euratom research was operating ad hoc; the Council could only adopt interim programmes on an annual basis.

The institutions openly acknowledged the Euratom crisis. In 1968, the Commission published a White Paper on 'Resolving the Euratom crisis', ${ }^{75}$ in which it claimed that most of the money went to national programmes that were not coordinated at European level. The Commission explained that the dispersion of research in the Community had 'prevented the effective establishment of a nuclear common market' ${ }^{76}$

From 1969 onwards, the Euratom started to set up 'supplementary programmes', which the Member States could participate in à la carte, i.e. they could choose which programmes they would participate in. ${ }^{77}$ The use of supplementary programmes has been described as 'diluting' the supranational aspects of the Euratom. ${ }^{78}$ Yet, they have become a central feature of the EU's general research and were institutionalised under the EEC Treaty by the Single European Act. In 1973, a new multiannual Euratom research programme was finally adopted. It was decided that the Euratom's research on industrial nuclear activities would be abandoned. ${ }^{79}$

It should also be mentioned that the Empty Chair Crisis of 1965 - the six-month French boycott of European institutions - also affected the Euratom: France did not attend meetings in any of the three Community Councils. However, as Droutman points out, the boycott might have had a positive effect on the Euratom - the crisis temporarily halted the bitter discussions on the Euratom research programmes during this period. ${ }^{80}$

75 'Pour sortir Euratom de la crise: Un livre blanc de la Commission Européenne', in Communauté Européenne, Novembre 1968, No 124, p 1, translated by the CVCE, www.cvce.eu/en/obj/resolving_the_euratom_crisis_ from_the_communaute_europeenne_november_1968-en-ab933c3f-a6d4-4eb5-8a4170d769a1df72.html, accessed 1 October 2017.

76 Ibid.

77 See Guzzetti, A Brief History of European Union Research Policy (n 73) 29.

78 Droutman, Nuclear Integration: The Failure of Euratom (n 66) 195.

79 One area that seemed to be immune from disagreements was nuclear fusion. The Council had approved a new five-year programme for nuclear fusion in 1971. The relative absence of disagreements can be explained by the fact that there were no direct industrial interests. See Guzzetti, A Brief History of European Union Research Policy (n 73) 12-15.

80 Ibid, 164. 
But while the Empty Chair Crisis was solved with the Luxembourg Compromise, ${ }^{81}$ the Euratom Crisis continued well into the 1970 s.

\subsection{CONCLUSIONS}

The Euratom Treaty was adopted to create economic prosperity and to ensure that Europe was not dependent on foreign energy sources. Some commentators also believed that the Euratom would be an important instrument for integration. When the economic and political realities changed, the Euratom's very rationale disappeared. It is in this context that we must situate the Euratom today. We will now move forward and examine the formal relationship between the Euratom and the EU.

81 The Luxembourg Compromise granted the Member States a veto over legislation that would threaten a 'vital interest'. On the Luxembourg Compromise, see, e.g., John Lambert, 'The Constitutional Crisis 1965-66' (1966) 5 Journal of Common Market Studies 140; and N. Piers Ludlow, The European Community in the Crises of the 1960s: De Gaulle Challenges the Community (London: Routledge, 2006). 
Anna Södersten - 9781788112253 Downloaded from PubFactory at 04/26/2023 10:58:27AM via free access 